\title{
Causes of poor management of the safety and hygiene program and compliance with STPS regulations
}

\section{Causas de la deficiente gestión del programa de seguridad e higiene y la atención a la normatividad de la STPS.}

\author{
RIVERA-CISNEROS, Miguel Ángel†*, RUIZ-ESPARZA-OCHOA, Sandra, MURILLO-SOTO, Sergio \\ and RAMÍREZ-SILVA, Macario Alejandro
}

Universidad Tecnológica de León, León Guanajuato, Mexico.

ID $1^{\text {st }}$ Author: Miguel Ángel, Rivera-Cisneros

ID $1^{\text {st }}$ Co-author: Sandra, Ruiz-Esparza-Ochoa

ID $2^{\text {nd }}$ Co-author: Sergio, Murillo-Soto

ID $3^{\text {rd }}$ Co-author: Macario Alejandro, Ramírez-Silva

DOI: $10.35429 / J I O .2020 .6 .4 .10 .17$

Received January 15, 2020; Accepted June 30, 2020

\begin{abstract}
This article presents results of the investigation that was applied to 17 companies in the city of León Guanajuato that requested support to establish the Safety and Hygiene plan in their organizations, its purpose is to identify the causes of poor management of the safety and hygiene program and attention to the regulations of the Ministry of Labor and Social Welfare (STPS). To carry out the investigation, information was collected through checklists in accordance with the STPS Official Mexican Standards (NOM), analysis tools were applied to identify the problem and a table was prepared to explain the causes. The result of the investigation revealed the main causes of the deficient management of the safety and hygiene program and compliance with the STPS regulations.
\end{abstract}

Management, Safety, Hygiene, Regulations, STPS

\begin{abstract}
Resumen
En el presente artículo se presentan resultados de la investigación que se aplicó a 17 empresas de la ciudad de León Guanajuato que solicitaron apoyo para establecer en sus organizaciones el plan de Seguridad e higiene, tiene como propósito la identificación de las causas de la deficiente gestión del programa de seguridad e higiene y la atención a la normatividad de la Secretaría de Trabajo y Previsión Social (STPS). Para llevar a cabo la investigación, se recopilo información mediante listas de verificación en conformidad con las Normas Oficiales Mexicanas (NOM) de la STPS, se aplicaron herramientas de análisis para identificar la problemática y se elaboró una tabla para explicar las causas. El resultado de la investigación arrojo las principales causas de la deficiente gestión del programa de seguridad e higiene y atención a la normatividad de la STPS.
\end{abstract}

Gestión, Seguridad, Higiene, Normatividad, STPS

Citation: RIVERA-CISNEROS, Miguel Ángel, RUIZ-ESPARZA-OCHOA, Sandra, MURILLO-SOTO, Sergio and RAMÍREZ-SILVA, Macario Alejandro. Causes of poor management of the safety and hygiene program and compliance with STPS regulations. RINOE Journal-Industrial Organization. 2020. 4-6:10-17.

\footnotetext{
*Correspondence to Author (Email: marivera@utleon.edu.mx)

$\dagger$ Researcher contributing first author.
} 


\section{Introduction}

The issue of occupational safety and hygiene is of utmost importance for organizations, since currently given the complexity of the processes, if preventive measures are not established in the risks of accidents and occupational diseases, the consequences can be very serious, especially all for the workers since all activity in companies carries risks. In accordance with the foregoing, it is possible to observe the importance of this investigation, which aims to identify the causes of poor management in companies to implement safety and hygiene programs and meet the obligation to comply with the Official Mexican Standards (NOM) of the Ministry and Labor and Social Security (STPS). This problem was identified in 17 companies in the city of León, Gto., Which requested support to carry out the safety and hygiene plan, of which 12 were industrial companies, and of these 11 were footwear manufacturers and 1 was a manufacturer of automotive parts, 3 service companies and 2 commercials.

Justification Health at work is very important, According to (Arias \& Heredia, 2009, p. 665) referring to the World Health Organization, as "a complete state of physical, mental and social well-being, to achieve full development of the human faculties "continue to cite the same authors that according to article 25 of the Universal Declaration of Human Rights" Everyone has the right to an adequate standard of living that ensures, as well as their family, health and well-being "(Arias \& Heredia, 2009, p. 665) and within work it is very important, since the worker is motivated by feeling safe and therefore potentiates their human skills at the service of organizations, hence the importance of establishing and implement Safety and hygiene in the work area. In accordance with the foregoing, it can be identified that there are organizations at the international level, such as the International Labor Organization (ILO) that proposes safety and hygiene measures for workers, thus establishing Human Rights principles, which countries should follow. to have a full development of social welfare.

For some authors "Mexico, as a country in the process of industrialization, is not alien to the implications that the production of goods and services and their usufruct brings with it, among which the accident rate is located in the various areas in which the human being operates "(Arias \& Heredia, 2009, p. 668).
It is necessary to consider it important that the Organizations establish adequate management, in order to coordinate efforts in favor of implementing the Safety and Hygiene program, in addition that this issue is of special interest since according to the LFT, article 475 Bis is cites that "The employer is responsible for safety and hygiene and the prevention of workplace risks in accordance with the provisions of the Law, its regulations and official Mexican standards" (Instituto Superior de Estudios Fiscales AC, 2014, p. 128).

Occupational safety and hygiene are tactics and strategies that are implemented within the organization, to reduce the risks of work due to accidents or occupational diseases, which has the purpose of procuring the care of workers, as well as generating health in the workplace. productive environment, so it is important to identify the importance of establishing a culture of prevention and thus preserve workers in optimal health conditions, so the managers of the organizations must implement Safety and Hygiene programs according to the needs protection of workers, also generating adequate awareness.

\section{Method description}

Quantitative Method, Research Design. It is a non-experimental method: Because you do not have control of the variables. Transversal: Because it took place in a single moment. Type of Research: Descriptive: Descriptive statistics were used. Research techniques: The record of measurements was carried out as follows:

- Checklist in accordance with the requirements of the NOM.

- Structured questionnaire: Applying the technique of the interview and the observation of the questionnaire. The way of carrying out the registration was in accordance with what is specified in ISO19011, guide for audits of the quality, environmental, safety and hygiene and information management system, where a comparison is made with the requirements of the NOM and the evidence of performance compliance, with two types of results, Conformity, Non-Conformity. 
- For the analysis of the information, the causes and the problem are identified in an Ishikawa diagram, as well as a Pareto diagram to identify the $80 / 20$ principle.

- To identify the causes, an explanatory table of relationship of requirement with the cause was used.

\section{Performance Evaluation Method:} Graphical rating scale method, focus on traits for performance evaluation where the management process is rated based on a scale of characteristics. (Bohlander \& Snell, 2009, p. 365).

The Universe object of study of this document are all the companies of the Municipality of León, Guanajuato, that require to establish and implement the occupational safety and hygiene program. The population under study in this document are 17 companies that requested advice, which had the need to establish and implement occupational safety and hygiene and meet the regulations of the STPS. The sample under study to represent the sequence of activities to document this document is from the companies that requested advice.

Work Hypothesis: H1: The lack of a culture of prevention of work risks and the ignorance of the application of the STPS regulations, are the causes that have as a consequence the deficient management in the implementation of the occupational safety and hygiene program and attention to the regulations of the STPS.

Null Hypothesis: H0: The lack of a culture of prevention of occupational risks and the lack of knowledge of the application of the STPS regulations are not causes that result in poor management in the implementation of the occupational safety and hygiene program and attention to STPS regulations.

\section{Development}

The results of the Investigation were the following:

1) From Methodological Objective 1 Request and Gather Information to identify variables. a) Managers and those in charge of the departments who would carry out the observation tour were asked, to identify the variables of the work risks, they were told that they will carry out their activities in a normal way, as they always do, all of them They agreed, the information could be collected without any problem.

\section{b) Design of Measurement Instruments:}

$\checkmark$ The design of the checklist was made in accordance with the requirements of the standards: NOM001_STPS_2008 Safety in Buildings, Grounds, Work Center areas, NOM002_STPS_2010 Prevention and Fire Fighting and NOM004_STPS_2010 Safety Devices in Machinery and Equipment; and its specific references NOM017_STPS_2010 Personal Protective Equipment and NOM026STPS, Colors and signs.

$\checkmark$ The Questionnaire List was prepared to identify the way to carry out the Management for the Implementation of the Safety and Hygiene Program and attention to the regulations of the STPS.

c) Compilation of information in the workplace, with the Observation technique, in accordance with the requirements of the NOM's, recorded in the checklist, identifying the compliance and non-compliance.

It was observed in the tour inside the company that risks were found, as presented in the Checklist, which is detailed below:

- 49 Conformities, that is, of the requirements requested by the standards applied according to the context of the company, in 49 requirements the company does comply.

- 43 Non-conformities, that is, it does not meet the 43 requirements established by the aforementioned standards. 
According to the above, it can be identified that, of the revised requirements, $53.26 \%$ do comply and $46.74 \%$ do not comply, it is important to identify that the percentages of non-compliance are very high, since the company must comply with $100 \%$ as established by the regulations in each of the STPS NOMs, since the fact that there are identifiable risks, each of the requirements that the company does not comply with would generate accidents and diseases on a large scale, due to the potentiality of each risk marked as non-compliance in the work area.

d) Compilation of the information from the questionnaire on how to carry out Management in the organization, with the Interview technique, through the objective registration of the information.

According to the questions made to those in charge of carrying out the Safety and Hygiene program and the attention to the STPS regulations, the percentage of compliance is represented according to the table, identifying the degree to which it complies and it was found that in companies:

- It is identified that the objectives are not specific, measurable, achievable, realistic and specify the time that must be met, also they do not have plans such as programs, procedures, budgets and documented regulations to achieve them, they do not take into account the regulations.

- The company does not comply with the documented organization formalized in organization charts, position profile, defined procedures, they do not have brigades to attend to emergencies, the staff has no specific tasks and they do not have resources to attend to Safety and Hygiene in the workplace.
- They did not show that there is effective supervision to carry out the tasks in accordance with the Health and Safety Plan; There is no intra-organizational communication to publicize the plan and meet the STPS requirements; there is no documented intra-organizational communication in writing when there are work risks, incidents and accidents for your attention; there is no motivation on the part of the coordinator to implement the regulations and attend the safety and hygiene plan; They do not have technical skills, how to apply the regulations and implement the health and safety plan.

- It does not have defined indicators to identify compliance with the health and safety plan and compliance with regulations; It does not have measurement instruments, to be able to measure the processes of the plan and compliance with the STPS regulations; It does not have time standards that measure performance according to the indicators, which are adequate to make effective decisions; they do not perform the analysis of the results that the performance measurement yields and take them as a basis for decision making; They do not carry out improvement, corrective and preventive actions, providing feedback on the processes to implement the Health and Safety plan and Attention to the STPS regulations.

2) From the methodological objective 2 . Analysis and Identification of the problem.

a) In the analysis and identification of the problem and the causes that generate it, the Ishikawa diagram was used, it was analyzed and identified that:

The problem is that there is a deficient management to implement the program of safety and hygiene and attention to the NOM's of the STPS; 
When carrying out the analysis of the causes, the non-conformities were taken as a basis by extracting the non-conformities to the NOM's, classifying them by problem stratum, identifying that the main causes are classified into 5 strata and that of the classification of nonconformities. compliance was identified that: There is ignorance in the application of the NOM's of the STPS, with 19 requirements that for this reason are not met. Being the biggest cause; There is a need for a culture of prevention of occupational risks, with 12 requirements that for this reason are not met; Regarding the lack of communication to implement the program, it was identified that there are 8 requirements for this reason that are not met; There is a lack of resources to implement the safety and hygiene program, it was found that there are 3 requirements that are not met with this cause; The lack of sanctions to avoid risks, 1 requirements are not met for this reason.

Ishikawa Diagram, Methodology of the Stratification or Enumeration of Causes Technique. (Gutiérrez Pulido, 2010, p. 197)

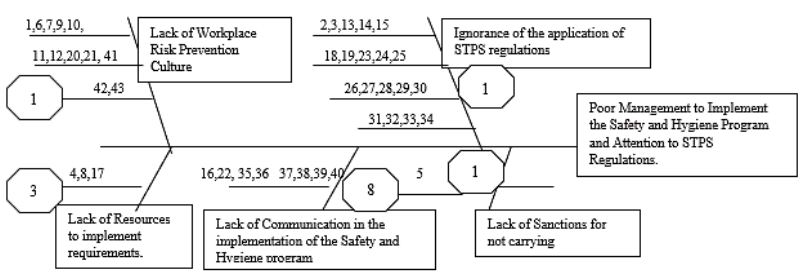

Figure 1

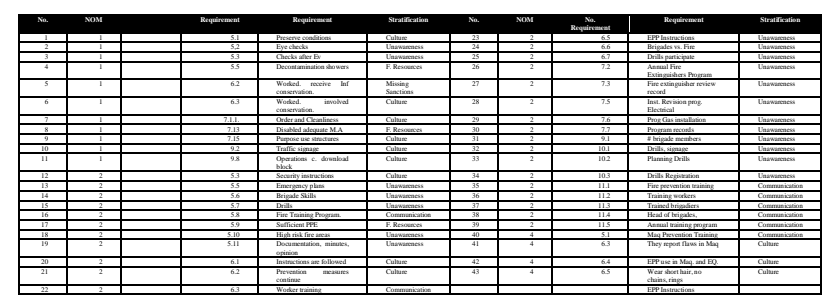

Table 1

b) In the analysis and identification of the problem and the causes that generate it, using the $80 / 20$ principle, to find the causal variables that cause the greatest number of problems, using the Pareto diagram, it was found that:
- In the lack of knowledge in the application of the NOM's of the STPS, the 19 requirements represent $44.19 \%$ and in the lack of a culture of prevention of work risks, the 12 requirements represent $27.91 \%$ and together according to the principle of Pareto, they represent $72.1 \%$ of the problems, so it can be identified that according to the stratification they are the main causes of the deficient management to implement the safety and hygiene program and meet the NOM's of the STPS. Pareto Chart: Analysis of the $80 / 20$ principle of the causes of poor Management to implement the Health and Safety program. (Gutiérrez Pulido, 2010, p. 179)

\begin{tabular}{|l|r|r|r|r|}
\hline \multicolumn{1}{|c}{ Cause Frequency } & \multicolumn{1}{c}{$\begin{array}{c}\text { Accumulated } \\
\text { Frequency }\end{array}$} & Percentage & \multicolumn{1}{c|}{$\begin{array}{c}\text { Accumulated } \\
\text { percentage }\end{array}$} \\
\hline $\begin{array}{l}\text { Ignorance of } \\
\text { regulations }\end{array}$ & 19 & 19 & 44.19 & 44.19 \\
\hline $\begin{array}{l}\text { Risk Prevention } \\
\text { Culture of }\end{array}$ & 12 & 31 & 27.91 & 72.1 \\
\hline $\begin{array}{l}\text { Lack of } \\
\text { communication }\end{array}$ & 8 & 39 & 18.60 & 90.7 \\
\hline $\begin{array}{l}\text { Lack of } \\
\text { resources of }\end{array}$ & 3 & 42 & 6.98 & 97.68 \\
\hline $\begin{array}{l}\text { Lack of } \\
\text { Sanctions of }\end{array}$ & 1 & 43 & 2.32 & 100 \\
\hline
\end{tabular}

Table 2

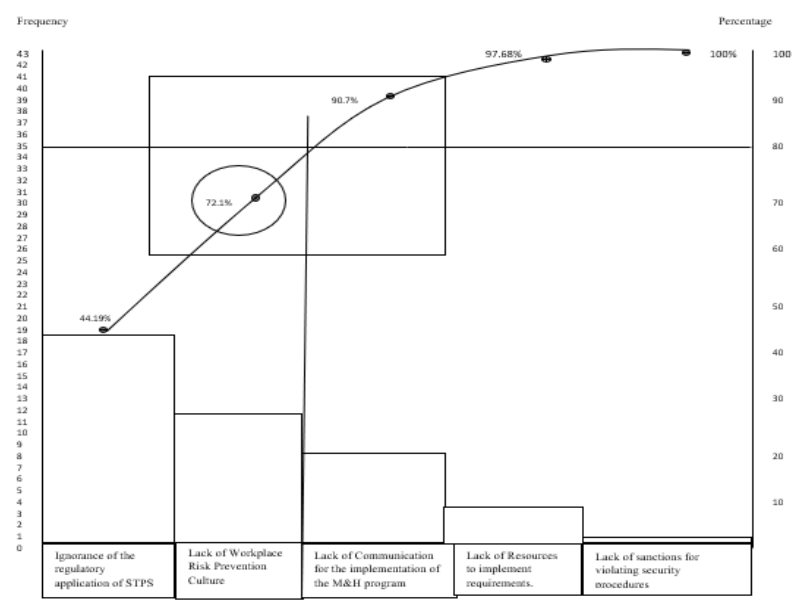

Figure 2 
From the Methodological Objective 3. Definition and explanation of the causes of the deficient management to implement the Safety and Hygiene program and attention to the NOM's of the STPS.

a) The table was designed to identify the requirements and their explanation of the causes, identifying the NOM requirement, which they did not comply with, the interpretation, the analysis of the expected / desired and the gap / difference.

Definition and Explanation of Causes by Stratum.

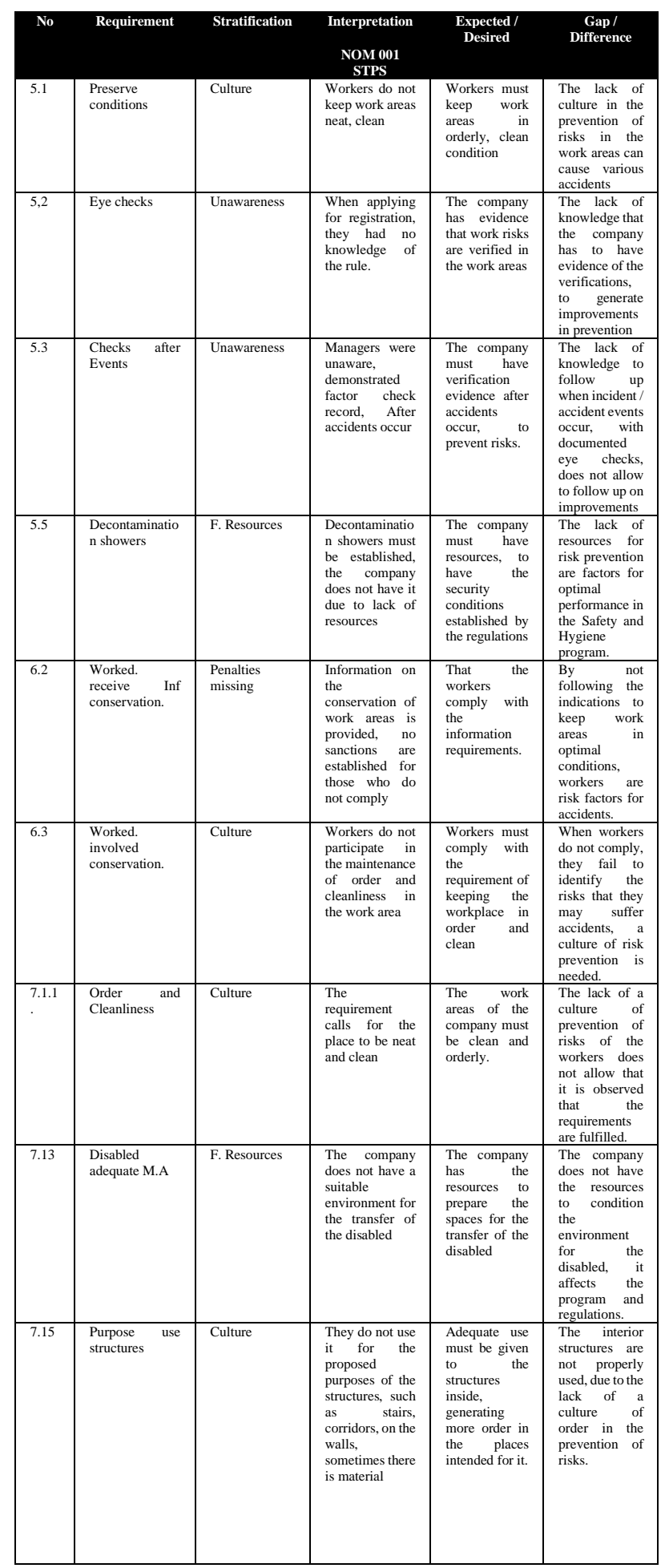

ISSN-2524-2105

RINOE® All rights reserved

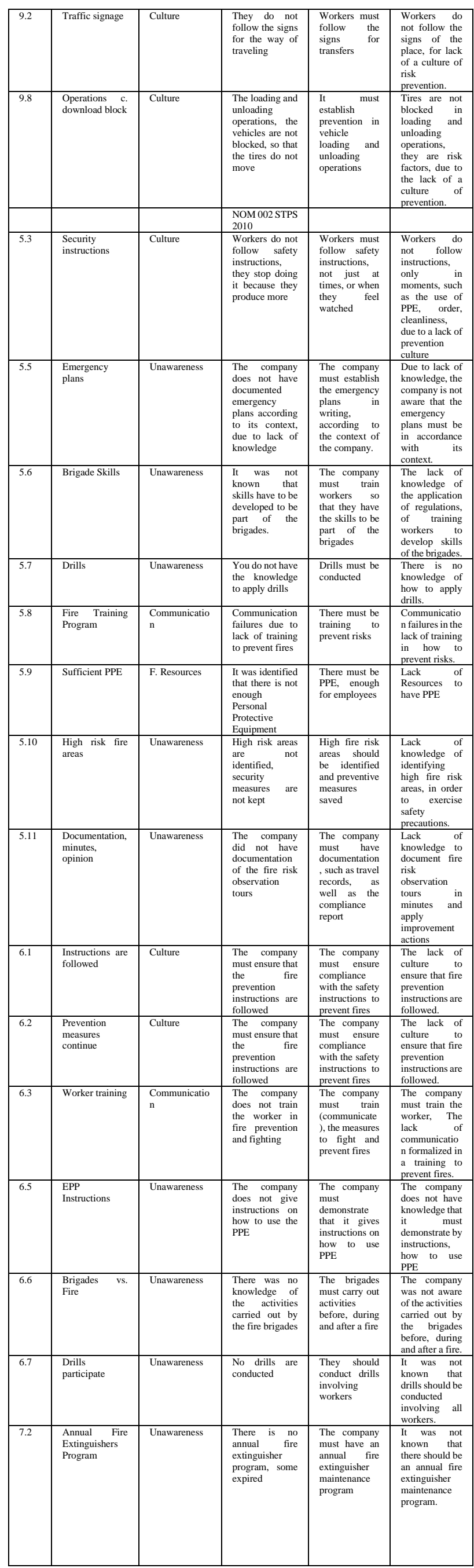

RIVERA-CISNEROS, Miguel Ángel, RUIZ-ESPARZA-OCHOA, Sandra, MURILLO-SOTO, Sergio and RAMÍREZ-SILVA, Macario Alejandro. Causes of poor management of the safety and hygiene program and compliance with STPS regulations. RINOE JournalIndustrial Organization. 2020 


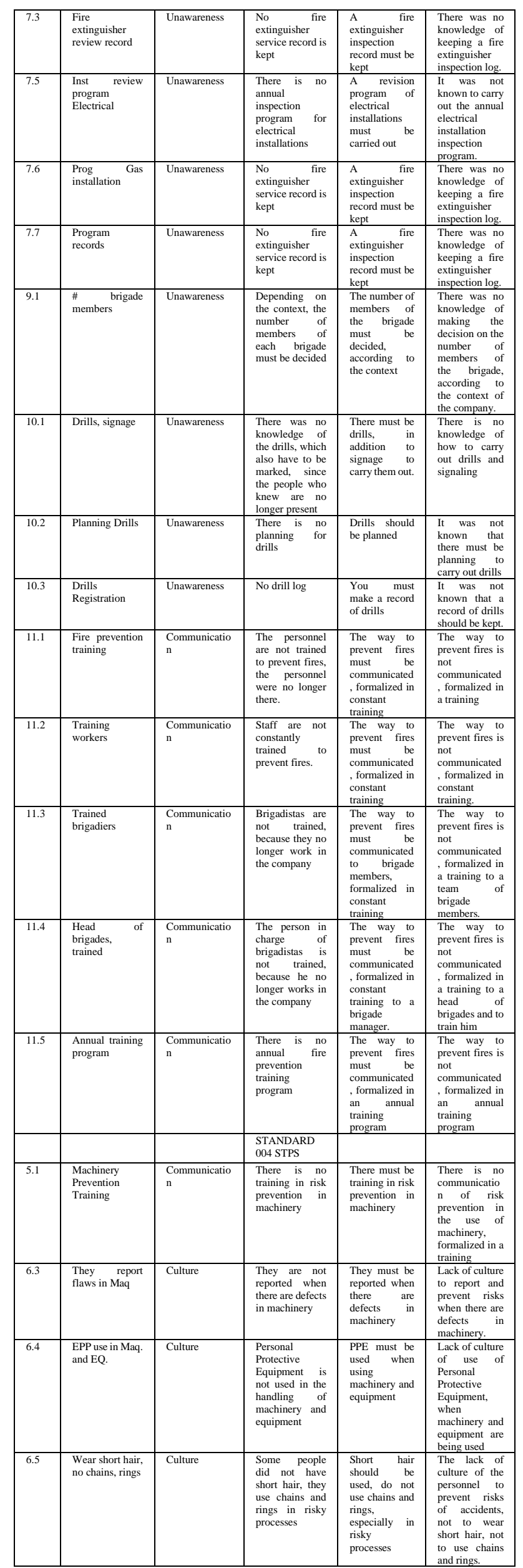

Table 3 Definition and explanation of causes by Stratum Source: Own elaboration

\section{Conclusions}

1. The causes that caused the deficient management to implement the safety and hygiene program and attention to regulations, is the ignorance of the application of the STPS regulations in the first place and in the second place the lack of a culture of prevention of occupational risks, being $72.1 \%$ of causes that cause the greater amount of problems.

2. It is very important that those in charge identify the type of NOM of the STPS according to the context of the company and apply the legal requirements that are stipulated in it, referring to the Legal Framework where standards related to Safety are identified for prevention of accidents, norms referring to Hygiene for the prevention of occupational diseases.

3. It agrees with the author Robbins (2004, p. 254) who asserts that culture is a "System of meanings shared by the members of the Organization, which distinguish it from others" and the author continues to cite that there are 7 characteristics to develop the Culture in the prevention of work risks, of which it is considered that: a) Innovate and take risks, to Implement Safety and Hygiene: Degree to which employees are encouraged to be innovative and take risks in the implementation of safety and hygiene; b) Thoroughness in implementing the Health and Safety program: Extent to which employees are expected to show accuracy, analytical skills and attention to detail; c) Orientation to the results of the Safety and Hygiene program: Degree to which management focuses on results; d) Orientation to people. Degree to which management decisions take into account the effect of the results on the members of the organization; e) Orientation to the teams. Degree to which work activities are organized in teams rather than individually; f) Aggressiveness to apply the safety and hygiene program: Degree to which people are daring and competitive, rather than carefree; g) Stability. Degree to which the activities of the organization maintain the state of safety and hygiene. 
4.- It is important that administrators must have the skills and competencies, in any of their areas of responsibility, to be successful and to achieve the goals of the organizations. The author Chiavenato (2008, p. 143) agrees that the administrator must have skills to carry out adequate management in: - Planning of the safety and hygiene program, appropriate to the context of the company, Adequate organization for the implementation of the program , Management Skills in the management for the implementation of Safety and Hygiene and attention to the regulations of the STPS, Adequate control to measure and provide feedback on the process of implementation of the Plan and attention to regulations.

5. It is important to follow research methods, analysis, start-up, to implement security measures in companies, as mentioned by the author (Lisa, 1999, p. 24) that it is important to have identified a model and establish planning suitable for its execution and corresponding improvement actions, hence the importance of approaching methodological models for its use.

6. It is relevant that an improvement plan be drawn up taking care of the gaps in which there is a discrepancy and making the best effort with responsibility between being and should be to achieve the objectives set regarding what is.

\section{References}

Arias, F., \& Heredia, V. (2009). Administración de Recursos Humanos para el Alto desempeño. México D.F: Trillas.

Chiavenato, I. (2008). Teoría General de la Administración. México: Mc Graw Hill.

Cortez, J. (2004). Seguridad e Higiene del Trabajo. México: Mc Graw Hill.

Díaz., J. M. (2002). Seguridad e Higiene del Trabajo. México.: Alfaomega.

Gutiérrez Pulido, H. (2010). Calidad Total y Productividad. México D.f.: Mc Graw Hill.

Instituto Superior de Estudios Fiscales A.C. (2014). Ley Federal de Trabajo. México D.F.: ISEF.
León., E. Z. (2014). Ley del seguro social. En E. Z. León., Ley del seguro social (pág. 129).

Lisa, A. R. (1999). Seguridad e Higiene en el trabajo. México: Alfaomega.

Mongosio, C. (2011). Seguridad e Higiene en el trabajo. México: alfaomega.

Robbins, S. (2004). Comportamiento Organizacional. México, D.f.: Pearson.

Secretaría de Trabajo y Previsión Social. (s.f.). Normas Oficiales Mexicanas. México D.f.: Diario Oficial de la Federación.

STPS. (2016). Cuarto Informe de Actividades. México, Df.: Secretaría de Trabajo y Previsión Social.

William, B. w. (1995). Seguridad e Higiene Laboral. México.

Zúñiga, A. H. (2003). Seguridad e higiene industrial . En A. H. Zúñiga, Seguridad e higiene industrial (pág. 92). Limusa. 